\title{
ZAWODNOŚĆ INSTYTUCJONALNA PAŃSTWA W ZAKRESIE STWARZANIA WARUNKÓW DO ROZWOJU PRZEDSIĘBIORCZOŚCI W KRAJACH EUROPY ŚRODKOWO-WSCHODNIEJ
}

\section{WSTĘP}

Przedsiębiorczość stanowi jeden z najważniejszych elementów kształtujących wzrost gospodarczy danego kraju. Praktyczne doświadczenia ostatniej dekady oraz dorobek teoretyczny nowej ekonomii instytucjonalnej pokazują, że głównym czynnikiem determinującym rozwój przedsiębiorczości jest efektywność systemu instytucjonalnego w danym kraju. Nowa ekonomia instytucjonalna w odróżnieniu od ekonomii głównego nurtu przyjmuje realistyczne założenie, iż instytucje ekonomiczne, takie jak państwo, prawo, czy też wymiar sprawiedliwości, nie są doskonałe. Recepcja określonych warunków instytucjonalnych przez podmioty gospodarcze skutkuje podejmowaniem przez nie zachowań dostosowawczych bądź zaradczych. W rezultacie podmioty zmuszone są do dodatkowych form aktywności, ponosząc koszty funkcjonowania systemu instytucjonalnego kraju. Koszty te w znacznej części wiążą się z niedoskonałością państwa, która przejawia się przede wszystkim w nieefektywnym ustawodawstwie i w wymiarze sprawiedliwości, a także w sferze bezpieczeństwa obrotu gospodarczego i stanie finansów publicznych.

Poziom analizy, jaki został zastosowany w niniejszym opracowaniu, charakteryzuje się połączeniem tzw. pozytywnej teorii politycznej - uwzględniającej wpływ warunków instytucjonalnych stwarzanych przez rząd na funkcjonowanie przedsiębiorczości, ze szczególnym uwzględnieniem jakości tworzonego prawa, zagwarantowania praw własności oraz najważniejszych elementów teorii kosztów transakcyjnych. W ramach tej ostatniej bazowano na typologii kosztów transakcyjnych uwzględniającej „twarde” i „miękkie” koszty transakcyjne. 
Celem opracowania jest próba weryfikacji oceny stanu i funkcjonowania wybranych rozwiązań instytucjonalnych krajów Europy Środkowo-Wschodniej wpływających na poziom kosztów transakcyjnych ponoszonych przez przedsiębiorstwa, co zgodnie $\mathrm{z}$ teorią kosztów transakcyjnych istotnie oddziałuje na zakres indywidualnej przedsiębiorczości. W artykule zwrócono szczególną uwagę na sytuację Polski w porównaniu z pozostałymi krajami Europy Środkowo-Wschodniej. Jako wspólny punkt odniesienia dla tej grupy krajów przyjęto trzy kraje wysoko rozwinięte: Stany Zjednoczone, Niemcy oraz Japonię.

\section{SYSTEM INSTYTUCJONALNY JAKO ŹRÓDŁO BEZPOŚREDNICH I POŚREDNICH KOSZTÓW TRANSAKCYJNYCH A PRZEDSIĘBIORCZOŚĆ}

Instytucje stanowią jeden z głównych czynników wpływających na efektywność gospodarki. Niemniej w literaturze ekonomicznej niewiele uwagi poświęca się jakości instytucji oraz kosztom transakcyjnym, które są przez nie generowane. Prace poświęcone zagadnieniom wzrostu gospodarczego skupiają się na innych czynnikach wpływających na poziom rozwoju gospodarki. Większość analiz koncentruje się na wielkości inwestycji w kapitał produkcyjny, oszczędnościach, inwestycjach w kapitał ludzki oraz postępie technologicznym ${ }^{1}$. W rezultacie ekonomiści stosunkowo rzadko koncentrują się na jakości instytucji w gospodarce. Wyjątkiem w tej materii są osiągnięcia teoretyczne ekonomistów związanych z nową ekonomią instytucjonalną ${ }^{2}$, których analizy uwzględniają historyczno-kulturowy kontekst procesu rozwoju gospodarczego. Można więc uznać, że są one bardzo wartościowym uzupełnieniem wysoce zoperacjonalizowanych teorii

\footnotetext{
${ }^{1}$ Współczesna teoria wzrostu gospodarczego osiągnęła znaczący postęp w zakresie analizy postępu technologicznego. O ile w neoklasycznym modelu wzrostu Solowa postęp technologiczny ma charakter egzogeniczny i jest traktowany jako „manna z nieba” (zob. R. M. Solow, Technical Change and the Aggregate Production Function, "Review of Economics and Statistics” 1957, vol. 39, no. 3, s. 311-320), o tyle w modelach endogenicznego wzrostu gospodarczego rozwijanych od połowy lat 80 . postęp technologiczny jest wyjaśniany przez inwestycję w badania i rozwój oraz jakość kapitału ludzkiego. (Zob. P. M. Romer, Increasing Returns and Long-Run Growth, "Journal of Political Economy" 1986, vol. 94, no. 5, s. 1002-1037; idem, Endogenous Technological Change, "Journal of Political Economy" 1990, vol. 98, no. 5, s. 71-102; P. Aghion, P. Howitt, A Model of Growth Through Creative Destruction, „Econometrica” 1992, vol. 60, no. 2, s. 323-351). Jednak teoria wzrostu gospodarczego cały czas w zasadzie abstrahuje od jakości systemu instytucjonalnego.

${ }^{2}$ Zob. O. E. Williamson, The Nerw Institutinal Economics: Taking Stock, Looking Ahead, ,Journal of Economic Literature", September 2000, vol. 38, s. 595-613; Z. Hockuba, Nowa ekonomia instytucjonalna - czy zdominuje nasze myślenie w rozpoczynajacym się stuleciu, [w:] A. Wojtyna (red.), Czy ekonomia nadq̨ża z wyjaśnieniem rzeczywistości, t. 1, PTE-Dom Wydawniczy Bellona, Warszawa 2001, s. 39-57.
} 
charakterystycznych dla ekonomii głównego nurtu, które nie uwzględniają kontekstu społecznego wzrostu gospodarczego ${ }^{3}$.

Dorobek nowej ekonomi instytucjonalnej wskazuje, że w długim okresie rozwój technologiczny, wzrost jakości kapitału ludzkiego oraz rozwój przedsiębiorczości jest możliwy i przynosi poważne efekty tylko w sytuacji, gdy towarzyszy mu efektywny system instytucjonalny, który gwarantuje wzrost zaufania społecznego pomniejszającego koszty transakcyjne w gospodarce ${ }^{4}$. Douglass C. North rozumie instytucje jako ograniczenia zachowań ludzkich, mające wpływ na jakość interakcji. Instytucje obejmują formalne zasady zachowania, nieformalne ograniczenia (normy zachowań, konwenanse, wzory postępowania). Instytucje są źródłem pewnych restrykcji w zakresie zawierania umów pomiędzy aktorami życia gospodarczego. W ten sposób instytucje wpływają na efektywność gospodarczą, determinując transakcje i koszty transakcyjne działalności gospodarczej ${ }^{5}$.

Traktując instytucje jako reguły gry na rynku, organizacje należy rozumieć jako aktorów życia gospodarczego. Realizując swoje podstawowe cele, tj. maksymalizację zysku, wygrane wybory, pożądaną regulację działalności, efektywną edukację, organizacje w postaci firm, partii politycznych, agencji rządowych, szkół, angażują wszelkie dostępne zasoby i umiejętności jednostek tworzących te organizacje $\mathrm{w}$ podejmowanie decyzji zapewniających efektywne przetrwanie w warunkach wszechobecnej konkurencji ${ }^{6}$. Ze względu na fakt, iż w gospodarce nie występuje sytuacja doskonałej informacji, podmioty muszą ponosić koszty związane ze zbieraniem niezbędnych informacji, a także dodatkowe koszty zawierania kontraktów. Tym samym można stwierdzić, iż koszty transakcyjne reprezentują straty zasobów, wynikające $z$ braku informacji ${ }^{7}$. Nie jest to jednak wyczerpująca definicja tego zjawiska. K. J. Arrow zdefiniował koszty transakcyjne jako „koszty funkcjonowania systemu gospodarczego"”. Według O. E. Williamsona koszty transakcyjne są dla systemu ekonomicznego tym, czym tarcie dla systemów fizycznych. Tarcie jest zjawiskiem powszechnie występującym i musi być brane

${ }^{3}$ Zob. szerzej: B. Polszakiewicz, J. Boehlke (red.), Ead instytucjonalny w gospodarce, t. 1-2, Wydawnictwo Uniwersytetu Mikołaja Kopernika, Torun 2005.

${ }^{4}$ D. C. North, Institutions, Transactions Cost and Productivity In The Long Run, „Economic History" 9309004, Ecin WPA, 1993, http://ideas.repec.org/e/prio11.html (28.03.2007).

${ }^{5}$ Idem, Economic Performance through Time, „American Economic Review” 1994, vol. 84, no. 3 , s. 359 i passim.

${ }^{6}$ Idem, Institutions, Transactions Cost..., s. 2.

${ }^{7} \mathrm{~J}$. Małysz, Instytucje a koszty transakcyjne w świetle neoinstytucjonalnej ekonomii, „Ekonomista” 2003, nr 3, s. 324.

${ }^{8}$ K. J. Arrow, The Organization of Economic Activity: Issues Pertinent to the Choice of Market versus Nonmarket Allocation, [w:] The Analysis and Evaluation of Public Expenditure: The PPB System, vol. 1, US Joint Economic Committee, $91^{\text {st }}$ Congress, $1^{\text {st }}$ Session, Washington DC, US Government Printing Office, s. 59-73; cyt. za: O. E. Williamson, Ekonomiczne instytucje kapitalizmu. Firmy, rynki, relacje kontraktowe, Wydawnictwo Naukowe PWN, Warszawa 1998, s. 32. 
pod uwagę w analizach fizycznych. Takiego samego postrzegania kosztów transakcyjnych brakuje ekonomistom, stąd konieczność nieustannego przypominania o kosztach funkcjonowania systemu ekonomicznego9 .

Współcześnie koszty transakcyjne rozumie się także jako koszty rozpoczęcia, wykonania i utrzymania efektów transakcji. S. N. S. Cheung określa koszty transakcyjne jako wszystkie koszty, które nie są rozważane w tak zwanej gospodarce Robinsona Crusoe ${ }^{10}$. D. C. North i J. J. Wallis dokonują rozróżnienia pomiędzy kosztami transformacji a kosztami transakcyjnymi. Koszty transformacji są ponoszone, kiedy zmianie ulegają fizyczne atrybuty dóbr i usług. Koszty transakcyjne ponoszone są z kolei, kiedy ulegają zmianie prawa własności dotyczące tychże dóbr i usług ${ }^{11}$.

Występowanie kosztów transakcyjnych zaprzecza możliwości istnienia gospodarki bez frykcji, stąd paradygmat neoklasyczny przestaje być użyteczny ${ }^{12}$. Opis gospodarki i poszczególnych uczestników musi zostać dokonany w ramach nowego paradygmatu uwzględniającego istnienie kosztów transakcyjnych. Dodatnie koszty transakcyjne wpływają na poziom opłacalności decyzji podmiotów. Pewne rozwiązania, które w warunkach braku kosztów transakcyjnych zostałyby podjęte, mogą zostać pominięte, ze względu na ich pomniejszoną przez koszty transakcyjne oczekiwaną użyteczność dla podmiotu podejmującego decyzje ${ }^{13}$. Koszty transakcyjne powodują zniekształcenie efektów decyzji podmiotów, stąd ważną kwestią jest zmniejszenie ich do poziomu najniższego z możliwych. Możliwe jest to dzięki zwiększeniu efektywności regulacji prawnych oraz efektywności instytucji państwa ${ }^{14}$.

Gdyby koszty transakcyjne były tylko kosztami koordynacji coraz bardziej skomplikowanej gospodarki, można by określić je mianem kosztów informacyjnych, powstających w efekcie konieczności zbierania coraz większej liczby informacji na temat gospodarki ${ }^{15}$. Niemniej koszty transakcyjne dotyczą również wprowadzania w życie umów oraz wdrażania wiarygodnych zobowiązań w czasie

${ }^{9}$ O. E. Williamson, Ekonomiczne instytucje..., s. 32.

${ }^{10}$ S. N. S. Cheung, Economic Organizations and Transaction Costs, ,The New Palgrave: A Dictionary of Economics” 1987, vol. 2, s. 55-58, za: F. A. G. den Butter, M. de Graaf, A. Nijsen, The Transaction Costs Perspective on Costs and Benefits of Government Regulation: Extending The Standard Cost Model, TI 2009-013/3, Tinbergen Institute Discussion Paper, 2009, s. 11.

${ }^{11}$ D. C. North, J. J. Wallis, Integrating Institutional Change and Technical Change in Economic History: A Transaction Cost Approach, „Journal of Institutional and Theoretical Economics” 1994, vol. 150, s. 609-611.

${ }^{12}$ D. C. North, Institutions, „Journal of Economic Perspectives” 1991, vol. 5, i. 1, American Economic Association, s. 97 i passim.

${ }^{13}$ M. Klaes, The history of the Concept of Transaction Costs: Neglected Aspects, "Journal of the History of Economic Thought" 2000, vol. 22, no. 2, s. 193-199.

${ }^{14}$ F. A. G. den Butter, M. de Graaf, A. Nijsen, op. cit., s. 12.

${ }^{15}$ Wyczerpującą analizę następstw związanych $\mathrm{z}$ istnieniem asymetrii informacji można 
i przestrzeni, niezbędnych do prowadzenia działalności gospodarczej. Przykładowo, współczesny przedsiębiorca ponosi koszty transakcyjne związane z postępującą specjalizacją produkcji, kontrolą jakości produktów w warunkach wydłużających się kanałów produkcji, czy też usiłując rozwiązać problem kosztownych relacji pryncypał - agent wewnątrz przedsiębiorstwa ${ }^{16}$. Można więc przyjąć tezę, że najważniejszym problemem każdego przedsiębiorcy, każdej ekonomicznej organizacji, jak również całego społeczeństwa jest rozpoznanie niepewności, która jest rezultatem braku szybkiej informacji bądź też zniekształcania informacji, i przeciwdziałanie jej ${ }^{17}$.

Przewidywalność rynku jest dostępna w stopniu ograniczonym nie tylko z powodu istnienia kosztów transakcyjnych scharakteryzowanych powyżej, które zazwyczaj uznawane są za konsekwencję istnienia niepewności losowej. Aktorzy życia gospodarczego, oprócz niepewności losowej muszą zmagać się również z niepewnością behawioralną, która dotyczy oportunistycznego zachowania innych podmiotów. Według O. E. Williamsona oportunizm polega na poszukiwaniu szczególnych korzyści (renty) w efekcie zniekształcania informacji, co powoduje asymetrię informacji wśród uczestników różnego rodzaju umów. Skłonność do oportunizmu wykazują tylko niektórzy aktorzy życia gospodarczego, niemniej wystarczy, aby kontrakty rynkowe nie były przewidywalne, by konieczne było tworzenie instytucji umożliwiających uporządkowanie rynku ${ }^{18}$. Biorąc pod uwagę dorobek nowej ekonomii instytucjonalnej, na szczególną uwagę zasługują zalecenia kompletności i przewidywalności przepisów prawa, wykluczających wszelką uznaniowość, właśnie w celu uniemożliwienia postaw oportunistycznych, czyli pogoni za interesem własnym przez urzędników państwowych.

W praktyce gospodarczej pojawia się kolejne bardzo ważne źródło kosztów transakcyjnych, które ma szczególny wpływ na rozwój przedsiębiorczości. Uwarunkowania rozwoju krajowej przedsiębiorczości determinowane są w głównej mierze przez ustawodawstwo rządowe, którego funkcjonujące $\mathrm{w}$ danym kraju firmy muszą przestrzegać. W wielu krajach rozwiniętych jakość tego ustawodawstwa jest tematem częstych dyskusji, zarówno w gronie praktyków gospodarczych, jak i teoretyków ekonomii. Ciężar danin publicznych ponoszonych przez podmioty gospodarcze jest oczywiście ważnym, bezpośrednim skutkiem dużej aktywności państwa w sferze gospodarczej ${ }^{19}$, co zmusza firmy do rekalkulacji zysków

znaleźć w pracy J. E. Stiglitz, The Contributions of the Economics of Information to Twentieth Century Economics, „Quarterly Journal of Economics”, November 2000, s. 1441-1478.

${ }^{16}$ D. C. North, Institutions..., s. 4.

${ }^{17}$ J. Małysz, op. cit., s. 330.

${ }^{18}$ O. E. Williamson, Ekonomiczne instytucje..., s. 60-62.

${ }^{19}$ Obecność państwa w sferze gospodarczej powinna być tutaj rozumiana jako aktywna rola rządu w procesie stymulacji gospodarki, zwłaszcza ekspansywna polityka fiskalna nakierowana na łagodzenie wahań koniunkturalnych powoduje w dłuższym okresie nierównowagę budżeto- 
z działalności i - w skrajnych przypadkach - może decydować o podjęciu decyzji opuszczenia rynku. Ponadto częste zmiany ustawodawstwa powodują niełatwe do zmierzenia, istotne koszty pośrednie prowadzenia działalności, gdyż wymuszają na operujących podmiotach koszty kolejnych dostosowań, zachwiany zostaje podstawowy rachunek marginalny firm, ogranicza to aktywność gospodarczą w warunkach niepewności legislacyjnej.

Dla przedsiębiorstw z krajów Europy Środkowo-Wschodniej okresem podwyższonego ryzyka dostosowań prawnych był czas, kiedy kraje te podjęły trud dostosowania ustawodawstwa do dorobku prawnego państw członkowskich UE, oraz czas już po akcesji, kiedy trwa nadal okres przejściowy w adaptacji do wspólnotowych przepisów prawnych. Oprócz tego samo ustawodawstwo wspólnotowe jest także niejednokrotnie źródłem dodatkowych kosztów transakcyjnych stanowiących barierę dla przedsiębiorczości. P. Tang i G. Verweij wskazali, że ograniczenie administracyjnego ciężaru, jaki powodują regulacje wspólnotowe, o 25\% spowodowałoby przyspieszenie wzrostu gospodarczego w krajach członkowskich UE o $1,7 \%$ realnego $\mathrm{PKB}^{20}$. Należy zatem wnioskować, iż ciężar regulacji administracyjnych wspólnego rynku europejskiego powoduje istotną stratę konkurencyjności przedsiębiorstw funkcjonujących na tym rynku w stosunku do ich konkurentów światowych. Ograniczenie tempa intensyfikacji powstawania nowych rozwiązań prawnych oraz ich ewentualnych zmian mogłoby stać się istotnym bodźcem stymulacji lokalnej przedsiębiorczości ${ }^{21}$.

Koszty regulowania warunków działalności podmiotów gospodarczych sprowadzają się zatem nie tylko do bezpośrednich danin umożliwiających utrzymanie aparatu rządowego. Są to także koszty koniecznych dostosowań podmiotów do zmian legislacyjnych oraz pewne koszty obowiązkowej sprawozdawczości przedsiębiorstw tworzonej dla organów administracyjnych egzekwujących stosowanie prawa. Koszty dostosowań legislacyjnych można podzielić na bezpośrednie koszty - podmiotów, których dotyczą konkretne rozwiązania prawne, oraz pochodne koszty - ciężar tych kosztów ponosi cała gospodarka, w sposób pośredni dostosowania legislacyjne naruszają równowagę w makroskali (tab. 1).

wą, a dalsze starania rządu powrotu do niskiego deficytu opierać się mogą na polityce nakładania wyższych poziomów opodatkowania na podmioty gospodarcze.

${ }^{20}$ Zob. P. Tang, G. Verweij, Reducing Administrative Burden in the European Union, CPB Memorandum, CPB Netherlands Bureau for Economic Policy Analysis, 25 August, http://www. cpb.nl/eng/pub/cpbreeksen/memorandum/93/memo93.pdf (7.05.2009).

${ }^{21}$ Konieczność ograniczania uregulowań administracyjnych prowadzenia działalności gospodarczej jest dostrzegana zarówno przez instytucje UR, jak i rządy poszczególnych państw członkowskich (zob. European Commission, Action Program for Reducing Administrative Costs in the European Union, Brussels 2007; UK Government, 25 ideas for simplifying EU law, URN 08/1138, Crown Copyright, London 2008; OECD, From Red Tape to Smart Tape. Administrative Simplification in OECD Countries, Paris 2003. 
Tabela 1. Gospodarcze efekty regulacji prawnych

\begin{tabular}{|l|l|}
\hline \multicolumn{1}{|c|}{ BEZPOŚREDNIE KOSZTY DOSTOSOWAŃ } & \multicolumn{1}{|c|}{ PoCHODNE EFEKTY DOSTOSOWAŃ } \\
\hline 1. Finansowe koszty (redystrybucja dochodu, po- & 1. Warunki konkurencji. \\
datki, ubezpieczenie społeczne, opłaty skarbowe, & 2. Społeczno-ekonomiczne efekty. \\
grzywny). & 3. Ograniczenie rozmiarów działalności gospo- \\
2. Obowiązki sprawozdawczości związane z obo- & darczej bądź zaniechanie części aktywności go- \\
wiązkami (sprawozdawczymi) podmiotów względem & spodarczej w warunkach legislacyjnej niepew- \\
państwa. & ności. \\
3. Wewnętrzne koszty przedsiębiorstw (koszty pro- & \\
wadzenia właściwej działalności gospodarczej, koszty & \\
pozyskiwania informacji, przeprowadzanie rachunku & \\
marginalnego). & \\
\hline
\end{tabular}

Źródło: opracowanie własne na podstawie: F. A. G. den Butter, M. de Graaf, A. Nijsen, The Transaction Costs Perspective on Costs and Benefits of Government Regulation: Extending The Standard Cost Model, TI 2009-013/3, Tinbergen Institute Discution Paper, 2009, s. 3.

Podsumowując, system instytucjonalny oraz poziom kosztów transakcyjnych będących jego pochodną determinują poziom przedsiębiorczości oraz efektywność gospodarki. Dobrze określone i zabezpieczone prawa własności, zdecentralizowany proces podejmowania decyzji politycznych i ekonomicznych, duża konkurencja tworzą zespół czynników sprzyjających rozwojowi przedsiębiorczości i stanowią fundament budowy nowoczesnej gospodarki zdolnej do czerpania korzyści ze zdobyczy nowoczesnej technologii ${ }^{22}$.

\section{KOSZTY TRANSAKCYJNE W POLSCE I POZOSTAŁYCH KRAJACH EUROPY ŚRODKOWO-WSCHODNIEJ NA TLE WYBRANYCH KRAJÓW WYSOKO ROZWINIĘTYCH}

Analiza jakości systemu instytucjonalnego oraz poziomu kosztów transakcyjnych będących jego pochodną corocznie przeprowadzana przez Bank Światowy dotyczy wszystkich najważniejszych aspektów prowadzenia działalności gospodarczej. Poniżej zaprezentowano wyniki krajów Europy Środkowo-Wschodniej, które przystąpiły kilka lat temu do Unii Europejskiej, na tle głównych gospodarek światowych: Stanów Zjednoczonych, Japonii i Niemiec. Zaprezentowane wyniki dotyczą kosztów rozpoczęcia działalności gospodarczej, kosztów związanych z uzyskaniem niezbędnych pozwoleń i licencji, kosztów rejestracji własno-

${ }^{22}$ Dla D. C. Northa poważnym dowodem na niemożliwość efektywnej biurokratycznej kontroli nad gospodarką, w warunkach niskiej konkurencji, przy braku ochrony praw własności oraz niskim poziomie przedsiębiorczości, jest nieudany eksperyment gospodarek centralnie planowanych (zob. D. C. North, Institutions, Transactions Cost..., s. 5). 
ści, kosztów egzekucji kontraktów oraz obciążeń fiskalnych. Powyższe kategorie kosztów transakcyjnych są w literaturze uznawane za główne czynniki ograniczające poziom przedsiębiorczości.

Tabela 2 przedstawia czynniki kształtujące poziom kosztów transakcyjnych związanych $\mathrm{z}$ rozpoczęciem działalności gospodarczej. Uwzględniono tu biurokratyczne i prawne przeszkody napotykane przez przedsiębiorcę uruchamiającego i rejestrującego nowe przedsiębiorstwo. Badanie to uwzględnia procedury, czas oraz koszt związany z zarejestrowaniem firmy zatrudniającej do 50 pracowników oraz posiadającej kapitał założycielski, który nie przekracza dziesięciokrotności PKB per capita danego kraju. W zaprezentowanym zestawieniu Polska osiąga znacznie gorsze rezultaty niż pozostałe kraje regionu w zakresie liczby wymaganych procedur, kosztu wykonania procedur, a szczególnie wymaganego minimalnego kapitału na uruchomienie działalności gospodarczej. W kwestii liczby niezbędnych do otworzenia działalności dni, dłużej trwa otwieranie własnego biznesu tylko w Bułgarii. Polska szczególnie źle wypada nie tylko w porównaniu z głównymi gospodarkami światowymi (Japonii, Niemiec i USA), ale przede wszystkim z gospodarkami regionu.

Tabela 2. Koszty podjęcia działalności gospodarczej w 2008 roku

\begin{tabular}{|c|c|c|c|c|}
\hline KRAJ & $\begin{array}{l}\text { LICZBA WYMAGANYCH } \\
\text { PROCEDUR PRZY REJE- } \\
\text { STRACJI FIRMY }\end{array}$ & $\begin{array}{c}\text { LICZBA DNI NIEZBĘDNYCH } \\
\text { NA WYKONANIE KAŻDEJ } \\
\text { PROCEDURY }\end{array}$ & $\begin{array}{c}\text { OFICJALNY KOSZT SPELNIANIA } \\
\text { PROCEDUR (\% DOCHODÓW } \\
\text { PER CAPITA)* }\end{array}$ & $\begin{array}{c}\text { WYMAGANY MINIMALNY } \\
\text { KAPITAL (\% DOCHODÓW } \\
\text { PER CAPITA)* }\end{array}$ \\
\hline Bułgaria & 4 & 49 & 2,0 & 47,8 \\
\hline Czechy & 8 & 15 & 9,6 & 31,8 \\
\hline Estonia & 5 & 7 & 1,7 & 23,7 \\
\hline Łotwa & 5 & 16 & 2,3 & 16,9 \\
\hline Litwa & 7 & 26 & 2,7 & 35,9 \\
\hline Polska & 10 & 31 & 18,8 & 168,8 \\
\hline Rumunia & 6 & 10 & 3,6 & 1,1 \\
\hline Słowacja & 6 & 16 & 3,3 & 30,4 \\
\hline Słowenia & 5 & 19 & 0,1 & 46,8 \\
\hline Węgry & 4 & 5 & 8,4 & 10,8 \\
\hline Japonia & 8 & 23 & 7,5 & 0,0 \\
\hline Niemcy & 9 & 18 & 5,6 & 42,2 \\
\hline USA & 6 & 6 & 0,7 & 0,0 \\
\hline
\end{tabular}

* Koszty rejestracji oraz wysokość wymaganego prawnie kapitału przy rejestracji spółki z ograniczoną odpowiedzialnością

Źródło: World Bank, Doing Business, 2009. 
W tabeli 3 ujęto koszty transakcyjne związane $z$ wypełnieniem wymaganych procedur, czasem oraz kosztem uzyskania pozwolenia na rozpoczęcie inwestycji budowlanej. Ujęto tu wszystkie niezbędne licencje oraz pozwolenia, przeprowadzanie wymaganych inspekcji oraz uzyskanie podłączeń do sieci usług komunalnych, niezbędnych dla funkcjonowania inwestycji. Z zaprezentowanego poniżej zestawienia jedynie Czechy oraz Węgry mają na podobnym, wysokim poziomie liczbę wymaganych procedur co Polska. W przypadku Polski realizacja niezbędnych procedur wymaga relatywnie dużo czasu i pociąga za sobą znacznie wyższe koszty niż w pozostałych krajach. W związku z tym Polska jest najgorzej oceniona w tej kategorii. Czechy, które wymagają spełnienia większej liczby procedur, gwarantują warunki sprzyjające ich szybszemu załatwianiu oraz zapewniają stosunkowo niski koszt spełnienia każdej procedury, dzięki czemu ich system instytucjonalny jest uznawany za bardziej sprzyjający przedsiębiorczości. USA, które uznawane są za najbardziej konkurencyjną gospodarkę na świecie, w tej kategorii rankingu ocenione są najlepiej spośród wiodących światowych gospodarek.

Tabela 3. Koszty uzyskania pozwoleń w 2008 roku

\begin{tabular}{|c|c|c|c|}
\hline KraJ & $\begin{array}{l}\text { LICZBA WYMAGANYCH } \\
\text { PROCEDUR PRZY INWESTYCJI } \\
\text { BUDOWLANEJ }\end{array}$ & $\begin{array}{l}\text { LICZBA DNI NIEZBĘDNYCH NA } \\
\text { WYKONANIE PROCEDUR }\end{array}$ & $\begin{array}{c}\text { OFICJALNY KOSZT SPEŁNIANIA } \\
\text { PROCEDUR (\% DOCHODÓW PER } \\
\text { CAPITA)* }\end{array}$ \\
\hline Bułgaria & 24 & 139 & 493,6 \\
\hline Czechy & 36 & 180 & 16,9 \\
\hline Estonia & 14 & 118 & 27,5 \\
\hline Łotwa & 25 & 187 & 20,6 \\
\hline Litwa & 17 & 162 & 109,9 \\
\hline Polska & 30 & 308 & 137,0 \\
\hline Rumunia & 17 & 243 & 91,2 \\
\hline Słowacja & 13 & 287 & 13,1 \\
\hline Słowenia & 15 & 208 & 112,2 \\
\hline Węgry & 31 & 204 & 10,3 \\
\hline Japonia & 15 & 187 & 19,1 \\
\hline Niemcy & 12 & 100 & 62,2 \\
\hline USA & 19 & 40 & 13,1 \\
\hline
\end{tabular}

* W badaniu szacowane są koszty oraz czas niezbędny do wykonania wszystkich procedur realizowanych dla przypadków standardowych inwestycji w tzw. normalnych okolicznościach.

Źródło: World Bank, Doing Business, 2009.

Tabela 4 prezentuje wyniki badania poświęconego kosztom rejestracji własności w przypadku standardowej sprawy przedsiębiorcy zamierzającego kupić 
nieruchomość w największym mieście w danym kraju, w sytuacji gdy nieruchomość ta jest już zarejestrowana oraz wolna od roszczeń własnościowych. W tym przypadku krajem najgorzej ocenianym jest Słowenia, ze względu na długi okres załatwiania sprawy. Polski system instytucjonalny ze względu na długi czas niezbędny na realizację każdej procedury jest oceniany jako drugi najbardziej nieefektywny. Problem ten może być uznawany za jedną z ważniejszych przyczyn utrzymującego się przez ostatnie lata relatywnie niskiego poziomu inwestycji w Polsce. Pośród gospodarek regionu w najbardziej kosztowny sposób rejestracja własności przebiega na Węgrzech. W niniejszym rankingu najlepiej wypada $\mathrm{Li}^{-}$ twa, której system instytucjonalny stwarza dla inwestora znacznie lepsze warunki aniżeli system amerykański.

Tabela 4. Koszty rejestracji własności w 2008 roku

\begin{tabular}{|l|c|c|c|}
\hline \multicolumn{1}{|c|}{ KRAJ } & $\begin{array}{c}\text { LICZBA WYMAGANYCH } \\
\text { PROCEDUR PRZY } \\
\text { REJESTRACI WtASNOŚCI }\end{array}$ & $\begin{array}{c}\text { LICZBA DNI NIEZBĘDNYCH } \\
\text { NA WYKONANIE KAŻDEJ } \\
\text { PROCEDURY }\end{array}$ & $\begin{array}{c}\text { OFICJALNY KOSZT } \\
\text { SPELNIANIA PROCEDUR } \\
\text { (\% WARTOŚCI } \\
\text { NIERUCHOMOŚCI) }\end{array}$ \\
\hline Bułgaria & 8 & 19 & 2,3 \\
\hline Czechy & 4 & 123 & 3,0 \\
\hline Estonia & 3 & 51 & 0,4 \\
\hline Łotwa & 7 & 50 & 2,0 \\
\hline Litwa & 2 & 3 & 0,5 \\
\hline Polska & 6 & 197 & 0,5 \\
\hline Rumunia & 8 & 83 & 2,4 \\
\hline Słowacja & 3 & 17 & 0,1 \\
\hline Słowenia & 6 & 391 & 2,0 \\
\hline Węgry & 4 & 17 & 11,0 \\
\hline Japonia & 6 & 14 & 5,0 \\
\hline Niemcy & 4 & 40 & 5,2 \\
\hline USA & 4 & 12 & 0,5 \\
\hline
\end{tabular}

Źródło: World Bank, Doing Business, 2009.

Tabela 5 przedstawia wyniki badania dotyczącego kosztów egzekucji kontraktów, uwzględniając liczbę procedur (kroków podejmowanych w celu przygotowania wniosku sprawy, czynności przed sądem oraz kolejnych działań związanych z wykonaniem wyroku), czas oraz koszty postępowania od początku rozpoczęcia sądowej procedury egzekucyjnej do momentu uzyskania płatności za kontrakt. W przypadku tej kategorii Polska jest jednym z gorzej ocenianych krajów w regionie. Pod względem wymaganych procedur gorzej wypada tylko Bułgaria, ze 
względu na liczbę dni niezbędnych do rozstrzygnięcia sporu Polska wypada najgorzej. Jedynie pod względem kosztu postępowania sądowego wypadamy korzystnie $\mathrm{w}$ regionie. Zdecydowanym zwycięzcą tego rankingu jest ponownie gospodarka amerykańska, zwłaszcza pod względem kosztów postępowania sądowego.

Tabela 5. Koszt egzekucji kontraktów w 2008 roku

\begin{tabular}{|l|c|c|c|}
\hline KRAJ & $\begin{array}{c}\text { LICZBA WYMAGANYCH } \\
\text { PROCEDUR }\end{array}$ & $\begin{array}{c}\text { LICZBA DNI NIEZBËDNYCH } \\
\text { NA ROZSTRZYGNĮCIE } \\
\text { SPORU }\end{array}$ & $\begin{array}{c}\text { KOSZTY POSTĘPOWANIA } \\
\text { SADOWEGO } \\
\text { (\% WARTOŚCI DŁUGU) }\end{array}$ \\
\hline Bułgaria & 39 & 564 & 23,8 \\
\hline Czechy & 27 & 820 & 33,0 \\
\hline Estonia & 36 & 425 & 18,9 \\
\hline Łotwa & 27 & 279 & 16,0 \\
\hline Litwa & 30 & 210 & 23,6 \\
\hline Polska & 38 & 830 & 12,0 \\
\hline Rumunia & 31 & 512 & 19,9 \\
\hline Słowacja & 30 & 565 & 25,7 \\
\hline Słowenia & 32 & 1.35 & 18,6 \\
\hline Węgry & 33 & 335 & 13,0 \\
\hline Japonia & 30 & 316 & 22,7 \\
\hline Niemcy & 30 & 394 & 14,4 \\
\hline USA & 32 & 300 & 9,4 \\
\hline
\end{tabular}

Źródło: World Bank, Doing Business, 2009.

W tabeli 6 zamieszczono koszty uiszczania podatków oraz innych obowiązkowych danin publicznych. Badaniem obciążeń fiskalnych objęto: podatek dochodowy podmiotów gospodarczych, obowiązkowe opłaty na ubezpieczenia społeczne, podatki płacone przez pracodawcę związane z zatrudnieniem, podatki od własności, opłaty od transferu własności, podatki od dywidendy, podatki od zysków kapitałowych, podatki od transakcji finansowych, podatki nakładane na posiadaczy samochodów oraz opłaty za użytkowanie dróg. Pośród kosztów ponoszonych przez przedsiębiorstwa w celu realizacji swojego obowiązku podatkowego należy głównie wymienić: koszty przygotowania, wypełnienia zeznania podatkowego oraz uiszczenia podatku, liczbę koniecznych płatności podatkowych, łączną kwotę zobowiązań podatkowych jako odsetek osiągniętych zysków przed opodatkowaniem. 
W zaprezentowanym badaniu liczba koniecznych płatności podatkowych obejmuje ilość tytułów obciążenia podatkowego, nie dotyczy częstotliwości uiszczania podatku - nawet jeżeli podatek jest uiszczany z dużą częstotliwością, w tej kolumnie wykazywany jest tylko raz. Wskaźnik czasu obejmuje liczbę godzin w roku, jaką należy poświęcić na przygotowanie, wypełnienie i zapłacenie trzech głównych rodzajów podatku: podatku dochodowego przedsiębiorstw, podatku VAT bądź innego od sprzedaży oraz podatku dochodowego zatrudnionych pracowników oraz innych socjalnych obowiązkowych płatności.

Pod względem liczby koniecznych płatności podatkowych w regionie gorzej od Polski wypada tylko Rumunia. Niemniej w zakresie czasu koniecznego na sporządzenie sprawozdania podatkowego i uiszczenia niezbędnych opłat Polska nie wypada źle w regionie. Pod względem łącznej kwoty zobowiązań podatkowych jako odsetka osiągniętych zysków pośród nowych członków Unii Europejskiej najkorzystniej wypadają kolejno Łotwa, Bułgaria i Słowenia. Najgorzej w rankingu uwzględniającym obciążenia fiskalne wypadają Węgry.

Tabela 6. Koszty uiszczania obowiązkowych danin publicznych

\begin{tabular}{|l|c|c|c|}
\hline \multicolumn{1}{|c|}{ KRAJ } & $\begin{array}{c}\text { LICZBA KONIECZNYCH } \\
\text { PtATNOŚCI PODATKO- } \\
\text { WYCH }\end{array}$ & $\begin{array}{c}\text { CZAS (W GODZINACH } \\
\text { W ROKU) }\end{array}$ & $\begin{array}{c}\text { ŁACZNA KWOTA ZOBOWIAZZAŃ PO- } \\
\text { DATKOWYCH JAKO \% } \\
\text { OSIĄGNIĘTYCH ZYSKÓW W 2007 R. }\end{array}$ \\
\hline Bułgaria & 17 & 616 & 34,9 \\
\hline Czechy & 12 & 930 & 48,6 \\
\hline Estonia & 10 & 81 & 48,6 \\
\hline Łotwa & 7 & 279 & 33,0 \\
\hline Litwa & 15 & 166 & 46,4 \\
\hline Polska & 40 & 418 & 40,2 \\
\hline Rumunia & 113 & 202 & 48,0 \\
\hline Słowacja & 31 & 325 & 47,4 \\
\hline Słowenia & 22 & 260 & 36,7 \\
\hline Węgry & 14 & 330 & 57,5 \\
\hline Japonia & 13 & 355 & 55,4 \\
\hline Niemcy & 16 & 196 & 50.5 \\
\hline USA & 10 & 187 & 42,3 \\
\hline
\end{tabular}

Źródło: World Bank, Doing Business, 2009.

W wyniku uwzględniania zaprezentowanych charakterystyk systemu instytucjonalnego Bank Światowy ocenił, że polski system instytucjonalny generu- 
je najwyższe koszty transakcyjne prowadzenia biznesu w regionie. W badaniu, w którym uwzględniono 181 gospodarek, Polska uplasowała się dopiero jako 76 kraj pod względem warunków sprzyjających przedsiębiorczości, podczas gdy kraje bałtyckie zmieściły się w grupie pierwszych 30 krajów, Słowacja zajęła 36, Węgry 41, Bułgaria 45, Rumunia 47, Słowenia 54, a Czechy 75 miejsce w tym badaniu $^{23}$. Oznacza to, że polski system instytucjonalny stanowi czynnik bardzo negatywnie wpływający na poziom prywatnej przedsiębiorczości. Uwzględnione w niniejszym opracowaniu kraje wysoko rozwinięte: Japonia, Niemcy i USA, zajęły w rankingu Doing Business odpowiednio: 12, 25 i 3 miejsce. W kontekście światowej konkurencji o inwestorów i inwestycje USA od wielu lat znajdują się w czołówce krajów cieszących się największym zainteresowaniem inwestorów, co zawdzięczają niewątpliwie swojemu efektywnemu i przyjaznemu dla biznesu systemowi instytucjonalnemu ${ }^{24}$.

\section{ZAKOŃCZENIE}

Przeprowadzona analiza ukazuje, że zarówno polski system instytucjonalny, jak i systemy instytucjonalne pozostałych krajów Europy Środkowo-Wschodniej są źródłem wysokich kosztów transakcyjnych. Niemniej w porównaniu z pozostałymi krajami Europy Środkowej w Polsce występuje największa liczba ograniczeń prowadzenia działalności gospodarczej. Ma to niewątpliwie negatywne konsekwencje dla poziomu przedsiębiorczości, tym samym stanowi zagrożenie dla średnio i długookresowego wzrostu gospodarczego.

Taki stan rzeczy jest szczególnie niekorzystny ze względu na konieczność nadrabiania bardzo dużych zaległości rozwojowych przez Polskę. Uwzględniając takie uwarunkowania, jak pełna otwartość granic, rosnąca internacjonalizacja i globalizacja, Polska, nie osiągając znaczących postępów w zakresie podnoszenia efektywności systemu instytucjonalnego i ograniczenia poziomu kosztów transakcyjnych, naraża się na osłabienie swojej międzynarodowej konkurencyjności. Oznacza to niższe tempo modernizacji kraju oraz gorszą pozycję np. w staraniach o napływ bezpośrednich inwestycji zagranicznych. Ponadto może to grozić przenoszeniem się najbardziej aktywnych rodzimych przedsiębiorców do krajów

${ }^{23} \mathrm{~W}$ badaniu tym oprócz zaprezentowanych kategorii oceniano także czynniki instytucjonalne wpływające na: koszt zatrudnienia pracownika, otrzymanie kredytu, poziom ochrony inwestora mniejszościowego przed nieuczciwym działaniem kadry zarządzającej, poziom obciążeń podatkowych, koszty regulacji dotyczących handlu zagranicznego oraz koszty zamknięcia działalności gospodarczej, które ze względu na ograniczone miejsce nie mogły zostać omówione w tej pracy.

${ }^{24}$ E. Rogalska, Kierunki przeptywu kapitatu z uwzględnieniem bezpośrednich inwestycji zagranicznych netto na świecie w latach 2004-2006, „Equilibrium” 2008, vol. 1, no. 1-2, s. 41-54. 
sąsiednich. Należy pamiętać, że osiągnięcie szybkiego efektu konwergencji w stosunku do pozostałych krajów wysoko rozwiniętych nie będzie możliwe bez wysokiego poziomu przedsiębiorczości wewnętrznej kraju.

\section{THE INSTITUTIONAL CONDITIONS OF ENTREPRENEURSHIP DEVELOPMENT IN CENTRAL EUROPEAN COUNTRIES}

SUMMARY

Entrepreneurship is a key element influencing the development of a country. Some experiences of the last century and some theoretical works of new institutional economics show that an institutional system is the main determinant of entrepreneurship activity. The ineffective institutional order that usually goes with low effectiveness of governance results in high level of insecurity in business processes. All market actors are forced to deal with a burden of additional transaction costs in that case. It has an unfavorable influence on the effectiveness of all businesses which must have significant influence on the level of entrepreneurship in an economy. The article aims at assessing the condition and functioning of chosen elements of the institutional system in Central and Eastern European countries in the field of creating the background for entrepreneurship. The article especially concentrates on comparative analysis of Poland with other countries of Central Europe and three highly developed countries USA, Germany and Japan treated as a benchmark. 